\title{
WHAT IS THE TITLE OF MERREW?
}

\author{
Islam I. AMER \\ Faculty of Arts, New Valley - Assiut University \\ E.mail: dreslam_amer@yahoo.com
}

\begin{abstract}
The title_fous was found on some vessels recovered from the pyramid of Djoser, followed by Mrrw (Merrew) the name of an unknown employee. This title is one of the mysterious and unclear titles. Researchers have offered various readings of this title (rmn zh?; zh ' (w)?; zh hrt-??), thus giving different meanings. The paper aims at identifying this employee through determining the most correct and closest reading of this title, deciding the time of its emergence, defining its meaning.
\end{abstract}

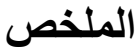

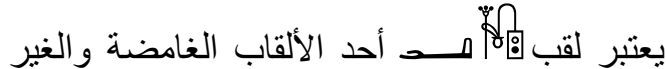
و اضحة، حيث قدم الباحثون قراءات مختلفة لهذا

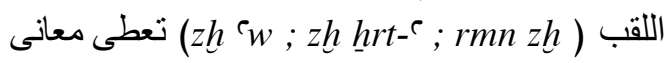
مختلفة له ـ ـويهدف البحث إلى تحديد القراءة الأقرب للصواب لهذا اللقب و تحديد وقت ظهوره ، وتحديد معناه ومهامه.

\section{KEYWORDS}

Djoser - Ninentjer - Mrrw (Merrew) - Scribe Bearer-Records - Documents
الكلمات الالة

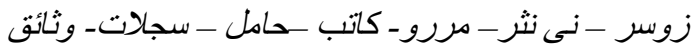

\section{INTRODUCTION}

The name Mrrw (Merrew) is inscribed in the Hieratic on vessels found in the Djoser pyramid. It noticed that the name is preceded in some vessels with unclear hieratic signs. Both Gunn and Lacau \& Lauer mentioned that they constitute the title ${ }^{1}$ _ f

This title is written in red ink on the remains of a dark diorite vessel. (Fig.1). The first sign is unclear and cannot be explained. The second sign according to Lacau \& Lauer is clear, a sign of $z h$ scribe $^{2}$, and it follows this title with the name $\delta$

\footnotetext{
${ }^{1}$ P. Lacau et J.-PH. Lauer, La Pyramide á Degrés, Inscriptions á L'encre Sur les Vases, Tome V, (Cairo, 1965), 60-61, no.144, fig.95; Nr.145, fig.96 = $(P D)$; B.Gunn, 'Inscriptions from the Step Pyramid Site, III Fragments of Inscribed Vessels', in: $A S A E, 28,(1928), 169-170$, fig. 17.
} 
The title was also written in red ink on the remains of a diorite bowl found in the corridors of the step pyramid of Djoser, with the same name and in the same form; only the arm sign was erased in its middle part (fig. 2$)^{3}$. There are different opinions about the time of the appearance of this title. Jones indicated that it appeared in the time of Djoser, ${ }^{4}$ because it was written on the vessels found in his pyramid. Kahl and Piacentini thought that it appeared in the second dynasty specifically in the reign of king Ninentjer ${ }^{5}$ because the time of these vessels dates back to this king. The obscurity of this title is due to the scarcity information available about the only holder of this title, Mrrw whose name was written on three pieces of diorite found in the pyramid of Djoser ${ }^{6}$; one of them, his name is written with the first part of this title_ (fig.3), but what is written on the others cannot be identified except "שe/IIIMrrw ${ }^{7}$. We shall attempt to identify this employee by reading this title, recognize its meaning as well as analyze, the time of its appearance and thus determine this employee's identity. The title is classified under the incomplete and unclear titles ${ }^{8}$ due to the ambiguity of its first part which constitutes the sign $ـ$. Is it an abbreviation of the word $\stackrel{-}{c}(w)$ which means documents/ recodes $^{9}$ ? Is it an abbreviation of the word $\rightarrow r m n$ which means bearer ${ }^{10}$, the word

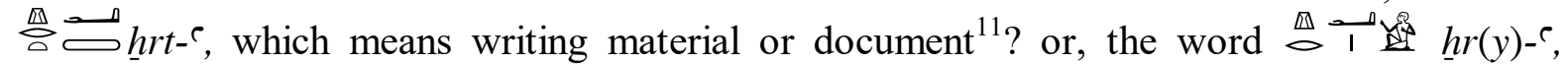
which means apprentice or assistant ${ }^{12}$ ?

\section{$r m n z h$}

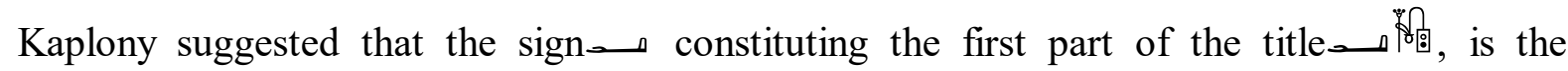
abbreviation of the noun rmn which means "bearer". Therefore; this title means "bearer of the writing tool/ scribe's outfit". He confirms the point of view that the word rmn was mentioned in one of the inscriptions of Djoser Pyramid with the meaning "to carry". He

\footnotetext{
${ }^{2}$ P. Lacau et J.-PH. Lauer, PD, V, no.144, fig.95, 60. It is noted that the hieratic sign which most researchers pointed out that it constitutes if is similar in Hieratic to the sign $\square$, so it is possible that these signs constitute

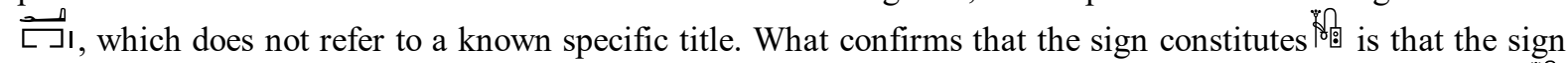
$\square$ was painted in Hieratic especially in old kingdom with connected, equal and sharp sides. Yet, the sign was painted with smooth, unequal sides, especially the upper side. Moreover, the left side was painted in a short form linked to a long stroke on the body of the writing tools to represent the bag of pens. This form is close to the sign painted on the vessels of Merrew. See. G, Möller, Hieratische Paläographie: die ägyptische Buchschrift in ihrer Entwicklung von der fünften Dynastie bis zur römischen Kaiserzeit, Bd.1 ,(Leipzig, 1909), Nr. 340, 32; Nr.537, 51. See Paleographic between the sing pr and sing zx .

${ }^{3}$ B.Gunn, ASAE, 28, (1928), 169-170, fig. 17

${ }^{4}$ D. Jones, An Index of Ancient Egyptian Titles, Epithets and Phrases of the Old Kingdom, Vol II, (Oxford 2000); Some Incomplete Unclear Titles, Nr.32, 1023.

${ }^{5}$ J.Kahl, Das System der ägyptischen Hieroglyphenschrift in der 0.-3. Dynastie, (Wiesbaden, 1994), 344 [26802681-2682]; P.Piacentini, Les Scribes dans la Soiété égyptienne de l'Ancien Empire ,Les Premiéres dynasties, Les nécropoles Memphies, Vol 1, (Paris ,2002), 49.

${ }^{6}$ P.Lacau et J.-PH. Lauer, PD, V, Nr.145, fig.96, 61.

${ }^{7}$ P.Kaplony, Die Inschriften Der Ägyptischen Frühzeit, Band, I, (Wiesbaden, 1963), 490. = $(I \ddot{A F})$.

Probably the name of this employee means "the beloved". See. P.Kaplony, Ï̈F , I, 490. cf. Rank.H, Die Ägyptischen Personennamen, Band I, (Glückstadt, 1935), 162, 17; 26.

${ }^{8}$ D. Jones, Index, II, Some Incomplete $\backslash$ Unclear Titles, Nr.32, 1023.

${ }^{9}$ Wb .I, 158, 19; R.Hannig, Die Sprache der Pharaonen Großes Handwörterbuch Deutsch-Ägyptisch, (Mainz, 2000), 1143 ; 1375; D. Meeks, Annee Lexicographique Egypte Anceinne, tome 1, 1977, (Paris, 1980), Nr.77.0549, 55; tome, II, 1978, (Paris,1981), Nr.78.0601, 60; tome III 1979, (Paris, 1982) ,Nr.79.0403, 41.

${ }^{10} \mathrm{~Wb}$.II , 419,19-20; R.Hannig , Handwörterbuch, 1305; D. Meeks, Alex I, Nr. 77.2377, 216;II, Nr. 78.2395, 221;III, Nr.79.1747, 169.

${ }^{11}$ Wb .III , 394, 1-3; D. Meeks, Alex ,II, Nr 78. 3229, 298; III, Nr.79.2348, 231.

${ }^{12}$ Wb .III , 393, 9-12; R.Hannig , Handwörterbuch, 495 D. Meeks, Alex I, Nr. 77.3272,295; II, Nr 78. 3228, 298; III, Nr.79.2347, 231.
} 


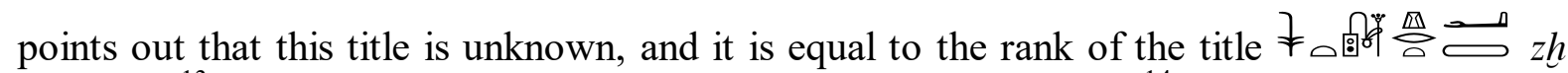
hrt- ${ }^{c} n s w t^{13}$ "Scribe of the writing material/ document-case of king" ${ }^{14}$ which was unknown in the archaic ages of the old kingdom ${ }^{15}$.

According to this point of view, the element $\mathrm{B}$ in this title constitutes the noun rmn, which means "bearer"16, derived from IV infirmae verb carry (function or rank) ${ }^{18}$. It is also read $r m n$; thus referring to "arm, shoulder, side" and meaning carrying (on the shoulder) ${ }^{19}$.So, It is concluded, from the meanings of this verb that it was probably used to refer to carrying the writing tools/ scribe's outfits including palette, usually with two concave places for inks, bag for the powdered pigments, and reed holder ${ }^{20}$. The numerous pieces of the outfits carried together -as in Hieroglyphic - are tied by a rope. This is evident from the reliefs of the tombs of the nobles who were proud of their ability to write, and they were not usually illustrated with writing tool/ outfits in the form of scribes. The most important of these reliefs are the cedar wood panels of the employee Hesy-Re from the third dynasty. One of these wood panels shows Hesy-Re seated with his palette and water vessel hung to his shoulder - by the tied rope - in the same way these outfits were always carried $^{21}$.

However, this means that the noun rmn refers not only to the carrying of writing tool/ scribe's outfits on the shoulder but also to individuals who carry anything, especially the priests who carry the chapel or a picture of the gods ${ }^{22}$. The noun was also mentioned in the pyramids texts as part of the expression rmn pt "supports, the sky"23/ "The bearer of the sky". It noticed that the expression is not a title but a special epithet of the priest in Dandera ${ }^{24}$. The noun was also used to refer to priests who carried the god rmn ntr, and the sacred objects in the

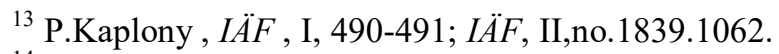

${ }^{14}$ D.Jones, Index, II, Nr. 3174; 867.

${ }^{15}$ P.Kaplony, $I \ddot{A F}$, I, 491.

${ }^{16}$ Wb .II , 419,19-20; R.Hannig, Handwörterbuch, 1305; D. Meeks, Alex I, Nr. 77.2377, 216;II, Nr. 78.2395, 221;III, Nr.79.1747, 169.
}

${ }^{17}$ Notes the determinative which constitutes the first part of the title $ـ$ is an ideogram of forearm and ${ }_{1}$ a arm. Handphona used as a substitute for many determinatives, different from the determinative $\longrightarrow$ which is always used with the verb and name rmn which illustrates a forearm with the palm of hand downwards. Kahl mentions that the name rmn was written with this determinative $\longrightarrow$ on stone vessels which were found in the pyramid of Djoser probably dating back to the second dynasty (?) and referring to a unit measurement (?). It was written with TA $\cong$, but the meaning is unclear .See A. H., Gardiner, Egyptian Grammar, Sign-list D.36, D.41, 454-455; J.Kahl, Fühägyptisches Wörterbuch, (Wiesbaden 2002), 268; P.Lacau et J.-PH. Lauer, PD, $\mathrm{V}, 29$.

${ }^{18} \mathrm{~Wb}$ II, 419, 4; A.Badawi\& H.Kees, Handwoerterbuch der Aegyptischen sprache ,(kairo 1958), 139.

19 A. H., Gardiner, Egyptian Grammar, Begin and introduction to the Study of Hieroglyphs, third edition, (London, 1973), 578.

${ }^{20}$ R.H. Wilkinson, Reading Egyptian Art: A Hieroglyphic Guide to Ancient Egyptian Painting and Sculpture, (London 1994), Y.3 A. H., Gardiner, Egyptian Grammar, Sign-list, Y.3; 534;

${ }^{21}$ R.H. Wilkinson, Reading Egyptian Art, Y.3. See. W. Wood, 'A Reconstruction of the Reliefs of Hesy-re', in: JARCE, 15, (1978).9-24.

${ }^{22}$ Wb. II, 419, 19-20; E. Naville, Das ägyptische Todtenbuch der XVIII. bis XX. Dynastie, (Beriln 1886), 152,6;71,16/7; Edfu, I, 560; J. Dümichen, Baugeschichte des Denderatempels und Beschreibung der einzelnen Theile des Bauwerkes nach den an seinen Mauern befindlichen Inschriften, (Strassburg - Trübner, 1877$), 31$.

${ }^{23}$ K. Sethe, Altaegyptischen PyramidenTexte, vol II, (Leipzig, 1910) 31; 517= Pyr, 952d; 2122cd.see.1156bc;1528a-c;2013a; R.O.Faulkner, The Ancient Egyptian Pyramid Texts, (Oxford, 1969), 164;301; S.A.B Mercer, The Pyramid texts, in translation and Commentary, ,( London 1952), Vol.I 268; 508; Vol II 486; Vol. III, 936. ${ }^{24}$ A.Mariette, Dendérah : description générale du grand temple, IV, (Paris ,1875), 34; A. Kamal, 'Le tombeau nouveau de Méîr (1913-1914)', in: ASAE, 16, (1916), 94. 
temple $^{25}$. It is noticed that the noun $r m n$, indicating to the "bearer", was not mentioned in the texts of the old kingdom and Middle kingdom as an element in one of the titles. Moreover, it rarely appeared as an element in the titles of the New kingdom; as most of them are religious titles ${ }^{26}$.

This is confirmed by the fact that the dictionaries of administrative and religious titles of the old and Middle kingdoms ${ }^{27}$, do not include any title in which the name rmn composes one of its elements, and it was not used in any text with writing tools or scribe's outfits. This indicates that Kaplony's view is incorrect and that the noun rmn is not an abbreviation of the first part $\_$of this title. Therefore, it does not mean "bearer of the writing tool/ scribe's outfit" 28 . This is confirmed in one of the texts which express the accompaniment of the young students to the educated artists in the old kingdom. Nekhebu says that he was the assistant of his brother, the overseer of workers, and he was writing and carrying his palette (scribe's outfit $\left.\breve{s}^{c}\right)^{29}$. It is noticed in this text that the verb rmn was not used to indicate carrying the scribe's outfit, but the prepositions $h r^{30}$ was used instead:

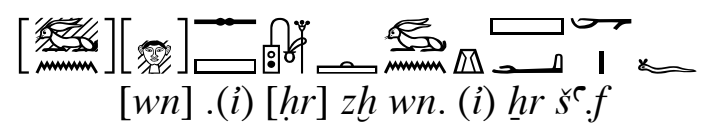

"(I) used to do the writing; ( I) used to carry his palette (?) ${ }^{31 "}$

\section{$z h^{\mathrm{C}}(w)$}

One of the readings proposed for this title - in case this reading was correct - means "scribe of records /documents" on the basis that the first part of this title $ـ$ is an abbreviation of the word c meaning record /document ${ }^{32}$ which always comes with the name nswt " king ",

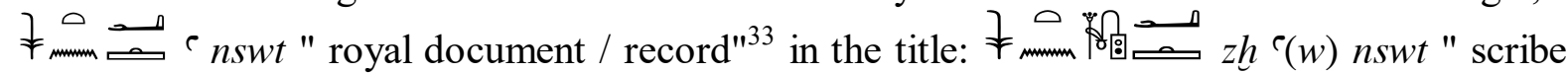
of the royal documents or records/ king's document scribe" ${ }^{34}$. This title probably appeared in

\footnotetext{
${ }^{25}$ D. Meeks, Alex II, Nr.78.2395, 221; Dendara. VIII,5,13,;84,3;90,5.7;117,3.6;G. Vittmann, Priester und Beamte im Theben der Spätzeit, (Wien,1978), 125, 168, n.8.

${ }^{26}$ See.C. Zivie, Giza au deuxième millénaire, (Le Caire 1976), 172 (C); rmni m HAt Imn "Bearer in front of Amun". See. S.Glanville, 'Scribes' palettes in the British Museum' in: JEA, 18.(1932), 55; CG 932= L. Borchardt, Statuen und Statuetten von Konigen und Privartleuten im Museum von Kairo, (Berlin 1930)161; rmni n Imn" bearer of Amun. See. D.G.Norman .Davies\& M.F. Macadam, A Corpus of Inscribed Egyptian Funerary, (Oxford, 1957), 203; Urk.IV, 1374, 17; 1952,2; rmni n imn Hr sA snnw" bearer of Amun in the second Phyle" CG.1107=L. Manniche, Lost Tombs. A Study of Certain Eighteenth Dynasty Monuments in the Theban Necropolis, (London 1988), 85.

${ }^{27}$ See. D. Jones, Index, II, 490-494; W.A.Ward, Index of Egyptian Administrative and Religious Titles of the Middle Kingdom, (Beirut, 1982), 101-104.

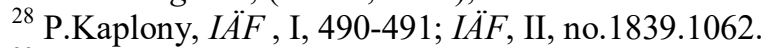

${ }^{29} \mathrm{~Wb}$ IV, 418, 8. See. D.Dunham, 'The Biographical Inscriptions of Nekhebu in Boston and Cairo, in: JEA, 24, (1938), 4, not.13.

${ }^{30}$ A. H., Gardiner, Egyptian Grammar, § 166,128.

${ }^{31}$ Urk.I, 216, 10; D.Dunham, JEA, 24, 4.

${ }^{32}$ Pyr.467c; 1519; Urk .I, 60,2; P.Posener-kriéger, Les archives du temple funéraire de Néferirkarê-Kakaï (Les papyrus d'Abousir). Traduction et commentaire, Vol II., (Le Caire 1976), 374(52A, 3c); K.Baer, 'A deed of endowment in a letter of the time of Ppjj I?', in: Z̈̈S, 93,(1966),7; H.Goedicke , 'Ein Brief aus dem Alten Reich (Pap.Boulaq. 8)', in: MDAIK, 22, (1967), 4

${ }^{33}$ Wb .I, 158, 19; III, 480, 14; R.Hannig, Handwörterbuch, 1375.

${ }^{34}$ D. Jones, Index, II, Nr.3057, 838; H.Brugsch, Dictionnaire géographique de l'ancienne Égypte, V, (Leipzig ,1880), 230
} 
the middle-late of the fourth dynasty and the beginning of the fifth dynasty ${ }^{35}$. There are many holders of this title in the old kingdom ${ }^{36}$. Many titles have been derived from this title, which are directly related to royal documents or records: $z h{ }^{{ }^{C}}(w) n s w t 3 h t$ " scribe of royal

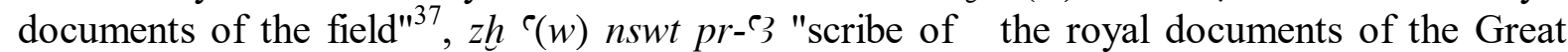
House" ${ }^{138}, z h^{\complement}(w)(n w) n s w t$ pr- ${ }^{\complement} m w^{\complement} b^{\prime \prime}$ scribe of the royal documents of the Great House in the workshop" ${ }^{39}, z h^{\complement}(w)(n w) n s w t$ pr- ${ }^{\complement} m$ prwy-nbw "scribe of the royal documents of the Great House in the two houses of gold"40, $z h^{\top}(w)(n w) n s w t h f t-h r$ " scribe of the royal records in presence, king's document scribe in the presence, personal scribe of the royal

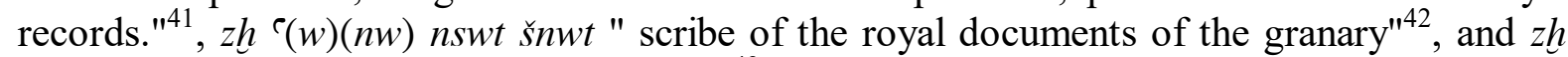
${ }^{c}(w)(n w) n t r r^{\prime \prime}$ document scribe of the god"43. Some of these titles continued to exist until the Middle Kingdom ${ }^{44}$ but with a little change.

This title is usually written without genitive $n$, but sometimes the genitive $n$ is added there too. There are many opinions ${ }^{45}$ concerning the position of the genitive $n$ in this title. Some examples of this title were found in forms in which the position of the genitive $\mathrm{n}$ changes as a result of the honorific transposition. However, the confirmed reading of this title: $z h^{\top}(w)$ $n s w t$ which means "scribe of the royal documents or records" ${ }^{46}$. It is noticed that the word $\sim$ c, a key element in all titles, is transcribed as ${ }^{c}(w)$, indicating plural. Ward thinks that this must be correct even though the word never appears in plural in any form of the

\footnotetext{
${ }^{35}$ See. Inscriptions of the Xnw-kA and N-KA-anX in Tehna Urk.I, 31, 17; 32, 9. Lefebvre and Moret, present some reasons to believe the Xnw-kA called hti might well have been the father of N-KA-anX. Hti probably lived at the very end of the Fourth Dynasty and N-KA-anX during the reign of Userkaf. See.N.Kanawati, The Egyptian Administration in the Old kingdom, (Warminster 1977), 56. See also titles of Isi (Middle to late fourth dynasty), titles of Nfr (Reign of Khafre or little later.), N. Strudwick, the Administration of Egypt in old Kingdom, (London, 1985), 65-66; 109-110; 202.

${ }^{36}$ Urk.I, 94, 8; 119,17; 285,11; A.Mariètte, Les mastabas de l'Ancien Empire, (Paris, 1889), E15, 419;

PM III2, O769; G.Daressy, Le mastaba de Mera, (Cairo 1900), 539; S.Hassan, Excavations at Giza, VI, part II ( Cairo 1948), 118 ; VI, part III, 9(11), VII, 26 , fig. 30; H. Junker, Gîza, III, (Leipzig. 1938), 141(2), fig.14,16; 219, fig.42; 222(1); G.Daressy, 'La nécropole des grands prêtres d'Héliopolis sous l'Ancien Empire', in : $A S A E$, 16, (1916), 198; H. G, Fischer, "The Inspector of Youths Nfr-n-2wfw", in : OMRO 41, (1960),6;n.21; T.G.H.James, Hieroglyphic Texts from Egyptian Stelae etc, in the British Museum, part I², (London 1962), nos.

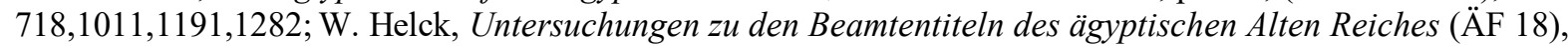
(Glückstadt 1954), 71, n.39,145; 72, n.42; W.K,Simpson, The Mastabas of Qar and Idu. G 7101 and 7102. (Giza Mastabas 2), (Boston 1976), 31,fig.36; P.Piacentini, Scribes , III, 1395.

${ }^{37}$ T.G. H, James, Corpus of Hieroglyphic Inscriptions in the Brooklyn Museum. I. From Dynasty I to the End of Dynasty XVIII, (Wilbour Monographs 6) ,(Brooklyn 1974)12[33],Pl.18(33); N. Strudwick, Administration, 26,212,n.4; P.Piacentini, Scribes, II, 618; 670.

${ }^{38}$ G.Daressy, ASAE, 16,(1916), 195,204; H. Junker, Gîza,VIII, 168(2),fig.88; A. Fakhry ,Sept tombeaux à l'est de la grande pyramide de Guizeh, (SAE) (Cairo 1935),12, fig.5; N. Strudwick, Administration, 210-212 ;P.Piacentini, Scribes, III , 1395, 1413(97).

${ }^{39}$ N. Strudwick, Administration, 106(77); N. Strudwick , 'The Overseer of the Treasury Ny-kAw-PtH', in RdE, 38, (1987) 139ff; H. G, Fischer, Egyptian Studies III. Varia Nova, (New York 1996), 34(a); 35, fig.4, 254; P.Piacentini, Scribes, II, 675; III, 1413(98).

${ }^{40}$ N. Strudwick, Administration, 106(77); idem, 38, 139ff; H. G, Fischer, Varia Nova, 34, n.40, 254.

${ }^{41}$ See D. Jones, Index, II, Nr.3063, 839-840.

${ }^{42}$ W. Helck, Beamtentiteln, 65,145; N. Strudwick, Administration, 61(12); P.Piacentini, Scribes, I, 376.

${ }^{43}$ T.G.H.James, HT I ${ }^{2}, 1319$; D. Jones, Index, II, Nr.3074, 843.

${ }^{44}$ zX an nsw ;zX an nsw n xft-Hr See. W.A.Ward, Index, nos. 1360, 1361, 1362, 1363, 1364, 158.

${ }^{45} \mathrm{~J}$ ones reading this title $\mathrm{zX} \mathrm{a}(\mathrm{w})$ (nw) nsw see. D. Jones, Index, II, Nr.3057, 838; Strudwick mention: in the fifth dynasty the title imy-r zx a n nswt was evidently sometimes read imy-r zx $n$ a nswt, with a extra n not belonging to the writing of nswt. The position of the $t$ of nswt varies in the fifth dynasty but in the sixth is most frequently written after the sedge plant, above the zx sign. See. N. Strudwick, Administration, 203.

${ }^{46}$ See Ward's discussion of the position of the $\mathrm{n}$ in this title W.A.Ward, 'Old Kingdom zx a $\mathrm{n}$ nsw $\mathrm{n} \mathrm{xft-Hr}$, "Personal Scribe of Royal Records", and Middle Kingdom zx an nsw n xft-Hr, "Scribe of the Royal Tablet of the Court', in: Or, 51, (1982), 383.
} 
numerous titles. He also states that the word, used primarily in ancient Egyptian texts, does refer to individual written documents and often to legal document ${ }^{47}$ of one type or another ${ }^{48}$.

The $`$ element is usually written $\underset{-}{\simeq}$, but it occasionally appears without the papyrus roll or with the papyrus roll written after the $z h \operatorname{sign}^{49}$. This indicates that this element is likely to be the one that forms the title _fof $\odot z h / z h \odot z h \odot(w)$ with the sign $z h$, "scribe of the documents /records", which probably appeared in the second dynasty and continued in this form until the third dynasty ${ }^{50}$, according to the date of the vessels on which this title was written. In the fourth dynasty, the word $n s w t$ was added to it, so it became $z h{ }^{\top} n s w t$ "scribe of the royal documents /records" ${ }^{51}$. Although Piacentinti suggested this reading ( $z h{ }^{`} w$ ?) for this title, she mentions that this reading is still doubtful due to the difficulty of anticipating that element $`$ precedes element $z h^{52}$. However, Ward mentioned that this title was written in six examples in this form $n s w t{ }^{c} z h^{53}$. Note that the element ${ }^{c}$ is written before the sign $z h$ -

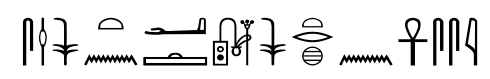

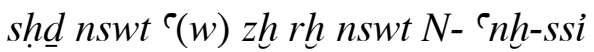

Inspector, the scribe of the royal documents/ records,

one know to the king $N-{ }^{-} n h-s s i .{ }^{54}$

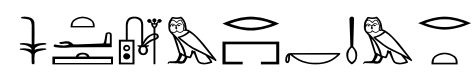

$N s w t^{\complement}(w)$ zh imy-r pr khrw-mrt

The scribe of the royal documents/ records, overseer of the house khrw-mrt. ${ }^{55}$

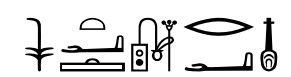

$$
N s w t^{\top}(w) z h R^{\complement}-n f r
$$

The scribe of the royal documents/ records, $R^{\mathrm{e}}-n f r^{56}$.

All this indicates that this title is the old form of the title $n s w t z h$ ', so it is derived from the title $z h \odot /\ulcorner z h>n s w t z h \odot n s w t<z h$ which was written in variant forms. Other titles related to records and documents were developed and derived from it ${ }^{57} . z h^{\odot} /\ulcorner$ h

\footnotetext{
${ }^{47}$ H.Goedicke, Königliche Dokumente aus dem alten Reich, (Wiesbaden 1967), 167; idem, Die Privaten Rechts inschriften aus dem Alten Reich, (Vienna 1970),188.

${ }^{48}$ W.A.Ward, Or, 51, (1982), 383.

${ }^{49}$ N. Strudwick, Administration, 203.

${ }^{50}$ P.Lacau et J.-PH. Lauer, PD, V, Nr.144, fig.95, 60; J. Kahl, Das System der ägyptischen Hieroglyphenschrift in der 0.-3. Dynastie, 344[2680-2681-2682]; P.Piacentini, Scribes, I, 49.

${ }^{51}$ N. Strudwick, Administration, 202- 203; D. Jones, Index, II, Nr.3057, 838.

${ }^{52}$ P.Piacentini, Scribes, I, 49; 46.

${ }^{53}$ W.A.Ward, Or, 51, (1982), 383.

${ }^{54}$ Urk I, 32,9

${ }^{55}$ L.Épron et F. Daumas, Avec un plan de. G. Goyon, Le tombeau de Tî, Fasc. 1, (Le Caire 1939), Pl. XXI.

${ }^{56}$ T. G. H .James, British Museum. Hieroglyphic Texts from Egyptian Stelae etc., Part I. Second Edition, (London 1961), No. 1011.Pl. XX.

${ }^{57}$ D. Jones, Index, II, 838-843.
} 


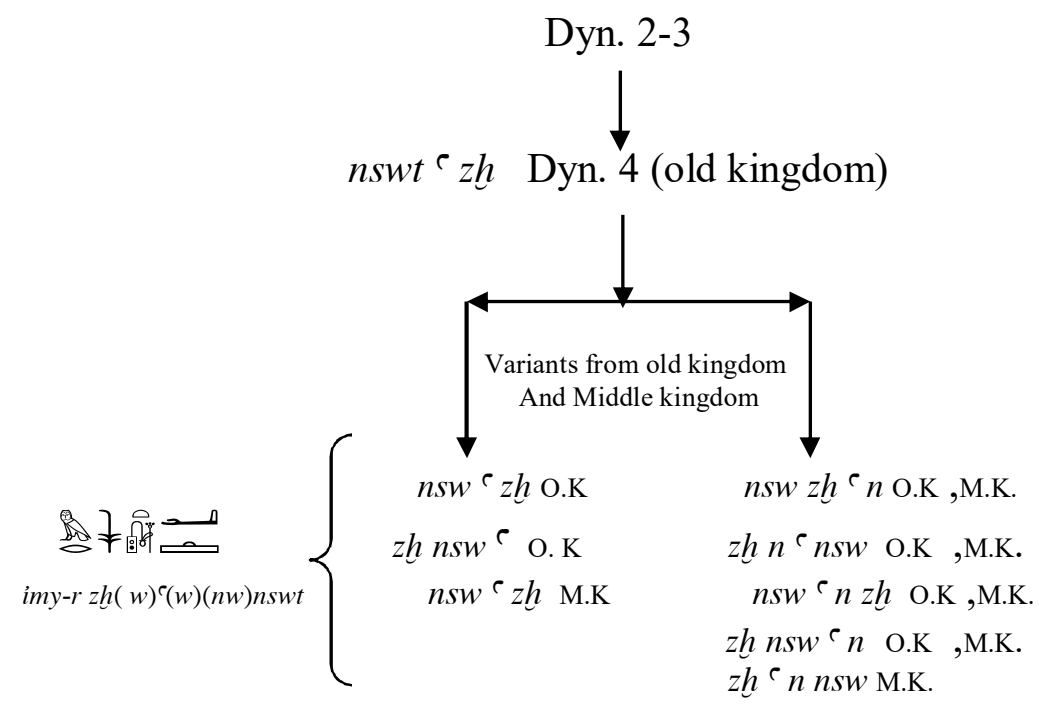

Overseer of scribes of the king's document

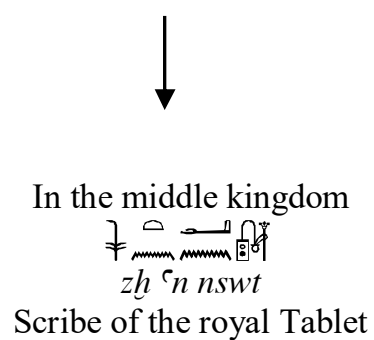

\section{$z h \underline{h} r t-e$}

The noun $\stackrel{0}{2}$ hrt- $^{\complement}$ means "writing material/document-case" ${ }^{58}$. This noun is derived from the noun $\underline{w} r$ - which appears in the coffins texts to indicate the tools bag ${ }^{59}$. It appears to be derived from the compound preposition 1 ...; / in the charge of ..."60 , a metonymy for keeping. The noun hrt- $^{-}$was used as an element

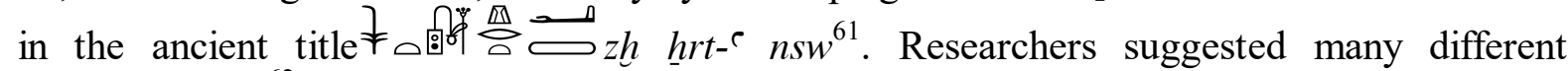
meanings for it $^{62}$.

\footnotetext{
${ }^{58}$ Wb .III, 394, 1-2; D. Meeks, Alex, II, Nr 78. 3229, 298; III, Nr.79.2348, 231; H.G.Fischer, 'Five Inscriptions of the Old Kingdom, in: $Z \ddot{A} S$, 105, (1978),54,n.64; A.Hermann, 'Buchillustrationen auf ägyptischen Bücherkästen', in: MDAIK, 15,(1957),112ff.

${ }^{59}$ Wb .III, 394, 4-5; W.V. Davies, 'Tutaankhamun's Razor-Box: A Problem in Lexicography', in: JEA 63, (1977), 109; K. Pflüger, 'The edict of king Haremhab', in: JNES, 5, (1946), 261; W.Helck, 'Das Dekret des Königs Haremheb,,in: Z̈̈S, 80 ,(1955), 117.

${ }^{60}$ A. H., Gardiner, Egyptian Grammar, § 178,132.

${ }^{61} \mathrm{~Wb}$.III, 394, 3. See. D. Jones, Index, II, Nr.3174, 867.

${ }^{62} \mathrm{LD}$ Text I, 12; A.Mariètte, Les mastabas de l'Ancien Empire, D.25, 253; G. Maspero, Études de mythologie et d'archèologie ègyptiennes, II, (Paris 1893-1916), 216, and n.2; H.Junker, Gîza, III, 219, fig.42; 222(2); H.F. Petrie \& M.A.Murray, Seven Mempite chapels, (London 1952), pl.4; Urk I, 231,8; PM III², O7; L.Epron \& H. Wild, Le Tombeau de Ti, I, ( Cairo 1939) pl.3; P. Montet, Les Scènes de la vie privèe dans les tombeaux ègytiens de l'Ancien Empire, (Paris 1925), 245, 146-7; B.Gunn , ASAE, 28, 169-170, fig.17; C.M.Firth\& J.E.Quibell, The Step Pyramid, II, (Cairo, 1939), Pl.90(1); W.Helck, Unterscuchungen zur Thinitenzeit, (Wiesbaden, 1987), 255, (13) ; W. Helck, Untersuchungen zu den Beamtentitln des Ägyptischen Alten Reiches, (Glückstadt, 1954) , 72, n. 42; A.Fakhry, The Monuments of Sneferu at Dashur, II, (Cairo, 1961), 5,
} 
Jones compared between this title and the title ${ }^{63}$ _fof and title__for is equal in rank to title $z h$ hrt-c nswt. He also mentioned that the only employee who held this title Mrrw was mentioned with the title $z h$ hrt- ${ }^{-} n s w t$ in inscription on a diorite vessel found in the a pyramid Djoser ${ }^{64}$ :

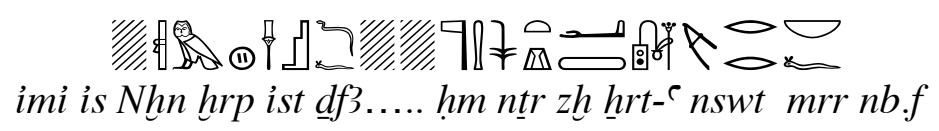

Overseer of the bureau of Nekhen, Director of the place of provisions ....... Prophet of ... Scribe of the writing material / document-case of king, beloved of his lord" ${ }^{65}$

Kaplony regarded the verb $\mathrm{mrr}$, meaning beloved and mentioned after $z h \underline{h}{ }^{-}{ }^{-}{ }^{-} n s w t$, as the name of employee Mrrw. He also considered it identical to the two names mentioned on the remains of a vessel and a bowl of diorite from the pyramid of Djoser with the title points out that Mrrw was Imy-r is Nhn as he is hrp ist $\underline{d} f$ 3. Moreover, he mentioned that the

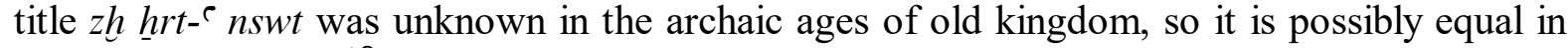

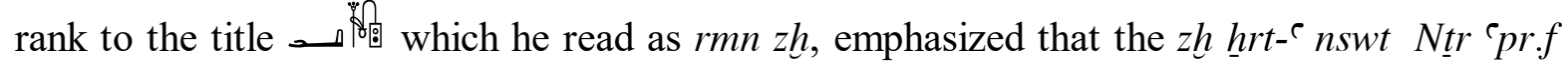
was an employee in the administration of districts, and the employee hpt -n-f was Imy-r is $N h n$ in an early period ${ }^{66}$.

Both Gunn and Helck disagreed with this view, and translated $m r r$ nb. $f$ "beloved of his lord "67. Helck mentions that this text is the titles of an employee who donated vessels to corridors of the pyramid, as the employee $s p 3$ and the priest of funeral temple of king $N b-k 3$ (3-i3hti who was overseer of the tomb of king Djoser $\operatorname{did}^{68}$.

This indicates that the reading of Kaplony rmn š̌ "bearer of the writing tool/scribe's outfit"

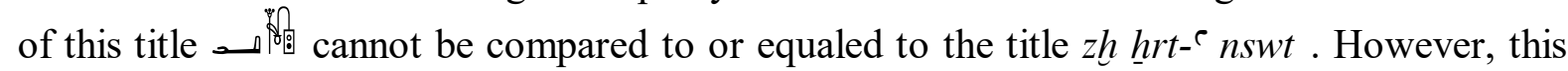

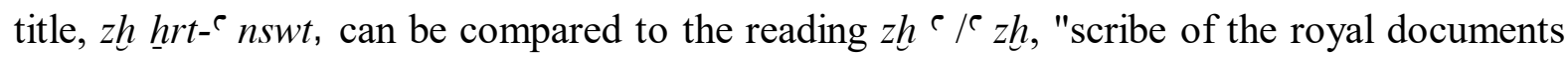
/records", due to their association with records and documents.

This name with determinative means "Assistant" 69 . It is probable that the first part $ـ$ of the title $ـ$ 期 is an abbreviation of

fig.283;idem, 'The Excavation of Snefru's Monuments at Dahshur. Second Preliminary Repot' in: $A S A E$, 52,1954, 563-594; W.Ward, Or, 51, 383, n.9; N. Strudwick, Administration, 61 (12); 139 n.130; 158 n. 157 ; 166 n.167; G.T. Martin, The Tomb of Hetepka and Other Reliefs and Inscriptions from the sacred Animal Necropolis ,North Saqqara 1964-73, (London, 1979), Pl.34 (98); D. Meeks, Alex I, Nr. 77.2373, III, Nr.79.2348; H.G. Fischer, Z̈̈S, 105, (1978),54 n.64; P.Kaplony, 'Der Schreiber, das Gotteswort und diepapyruspfianze Mit neuen untersuchungen zum unter ägyptischen Königtum’ , in: Z̈̈S , 110, (1983),167; J.Kahl, Das System der ägyptischen Hieroglyphenschrift in der 0.-3. Dynastie, 616, 736, 833, nn. 1458, 2316, 2319; J.Assmann, Die Mastaba II / I zu Dahschur-Mitte, (Heidelberg, 1992), 91, fig. 26.

${ }^{63}$ D. Jones, Index, II, Some Incomplete $\backslash$ Unclear Titles, Nr.32, 1023.

${ }^{64}$ P.Kaplony, Ï̈F , I, 490-491; B.Gunn, ASAE 28 (1928), P1. III, 1,2. 162.

${ }^{65}$ W. Helck, 'Die Datierung der Gefäßaufscriften aus der Djoserpyramide', in: Z̈̈S, 106, Heet 2, (1979),130;

B.Gunn, ASAE 28, 162.

${ }^{66}$ P. Kaplony , Ï̈F I, 490-491.

${ }^{67}$ B.Gunn, ASAE 28, 162; W. Helck, Z̈̈S, 106, Heet 2, (1979), 130.

${ }^{68}$ W. Helck, Z̈̈S, 106, Heet 2, (1979), 130

${ }^{69} \mathrm{~Wb}$.III , 393, 9-12; R.Hannig, Handwörterbuch, 495 D. Meeks, Alex I, Nr. 77.3272,295; II, Nr 78. 3228, 298; III, Nr.79.2347, 231; P. Posener-Kriéger, Les archives du temple funéraire de Néferirkarê-Kakaï (Les papyrus

- 44 - What is the title of Merrew? 
this name, so the meaning of the title is "Assistant scribe" who is under his hands. Thus; this name literally means "under the hand of"/ Assistant of, but there is no evidence that the name is the first part of this title. According Jones this name was used individually as a title in this meaning in the old kingdom ${ }^{70}$. It was also used in the Middle kingdom and New kingdom as a title referring to "Apprentice" ${ }^{71}$, who was receiving more advanced education in a specific office or profession in order to take up the same profession as their lords ${ }^{72}$.

It is noticed that the various readings proposed for this title agree that the second element of this title is $z h^{73}$. This indicates that Mrrw (Merrew) ${ }^{74}$ who held this title belonged to the class of scribes. However, due to lack of agreement reading a specific reading for this title, it is not possible to determine to which class of scribes Merrew belonged. The following readings rmn $z h$, hry- ${ }^{c} z h$ of this title refer that he was a young scribe, an assistant, apprentice for a great scribe and holder of his tools ${ }^{75}$. While discovering the Merrew vessels carrying this title inside the pyramid of Djoser indicates that Merrew was a major scribe and one the major employees and priests who donated their vessels to the pyramid of Djoser.

However, the date of these vessels, which goes back to King Ninentjer ${ }^{76}$ of the Second Dynasty, indicates that the title's holder was an employee in the reign of this king, during which the government organization developed, and different administrations emerged ${ }^{77}$. Many inscriptions that were found carved on many stone vessels dating back to the reign of this king inside the corridors of the pyramid of Djoser, mentioned the names of employees and the names of buildings. It is possible that some of these corridors, located at the bottom of the Djoser group, especially those in the western pyramid, were originally the lower buildings of the large tombs of the second dynasty that King Djoser removed ${ }^{78}$.

d'Abousir), I, (Caire, 1976), 113; H.G. Fischer, Z̈̈S, 105, (1978), 54 ; G.T Martin, 'Private-Name Seals in the Alnwick Castle Collection', in: MDAIK 35 (1979), 217.

${ }^{70}$ D. Jones, Index, II, Nr.2827, 777; P.E Newberry, Egyptian antiquities : scarabs; an introduction to the study of Egyptian seals and signet rings, (London 1906), 262 (2599), 116, P1.8 (8); P. Posener-Kriéger, Archives Abousir,II,659;N. Strudwick, Cylinder Seals of the Old kindom, (Oxford ,1978), 45 (78), 75,78 and P1.7, 5.19, 5.20; P.Kaplony, Die Rollsiegel des Alten Reiches. II: Katalog der Rollsiegel, (Bruxelles, 1981), Pl. 55(32); W. Kaiser, \&Others, 'Stadt und Tempel von Elephantine. 13./14. Grabungsbericht',in: MDAIK, 43, (1987), 109.

${ }^{71}$ See. W.A.Ward, Index, no. 1194,139; P.A.A. Boesser, Beschreibung der Aegyptischen Sammlung der Niederländischen Reichsmuseums der Altertümer in Leiden, II, (Leiden 1909), no.33; T.G.H. James, The Hekanakhte Papers and Other Early Middle Kingdom Documents, (New York, 1962); no.XII, 5; CG 20026, 20720. See. xry-a n Hm.f M. Sandman, Texts from the time of Akhenaten , (Bruxelles, 1938), 175.14; P. Anastasi IV, 1a,1= A.Gardiner, Late-Egyptian Miscellanies, (Bruxelles, 1937), 34.

${ }^{72}$ A.Gardiner, 'The House life', in JEA, 24, (1938), 159; J. Baillet, 'Les noms de L'esclave en Égytian' in: $R T=$ RecTrav, 28, (1908), 124.

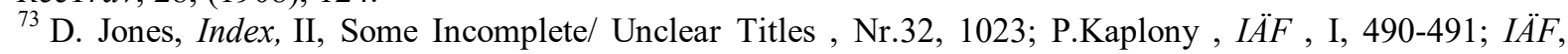
II,no.1839.1062; P.Lacau et J.-PH. Lauer, PD, 60-61, no.144, fig.95; Nr.145, fig.96; B.Gunn, ASAE, 28, (1928), 169-170, fig.17; P.Piacentini, Scribes, I, 49; 46.

${ }^{74}$ Kaplony mentions that his name means beloved and can be compared to the name Mrr and also the name Mrrw.see P.Kaplony, Ï̈F , I, 490-491;see.H. Ranke, Die Ägyptischen Personennamen, Band. I, (Glückstadt ,1935), 162,17; 26.

${ }_{75}$ R.Hannig, Handwörterbuch, 495 D. Meeks, Alex I, Nr. 77.3272,295; II, Nr 78. 3228, 298; III, Nr.79.2347, 231; P. Posener-Kriéger, Les archives du temple funéraire de Néferirkarê-Kakaï (Les papyrus d'Abousir),I, ( Caire, 1976), 113; H.G. Fischer, ZÄS, 105, (1978),54 ; G.T Martin, MDAIK 35 (1979), 217; see Notes 67; 68; 69.

${ }^{76}$ J.Kahl, Das System der ägyptischen Hieroglyphenschrift in der 0.-3. Dynastie, 344[2680-26812682];P.Piacentini, Scribes 49.

${ }^{77}$ W.Helck, 'Ninetjer', in: $L \ddot{A}$ IV, (1982), 509.

${ }^{78}$ A.J., Spencer, Early Egypt. The Rise of Civilisation in the Nile Valley, Translated to Arabic by A.Aldali, review by T.Hindusa, (Cairo 1991), 129-130. 
Helck also mentioned that the large part of the ink inscriptions on the stone vessels, found in the pyramid of Djoser, were written during the reign of king Ninentjer especially in Hebsed festival, but apparently these vessels were not used. Then, they were later placed in the eastern corridors of the tomb by Djoser. This indicates that reign this king witnessed the development of ruling and administrative systems ${ }^{79}$. It was previously mentioned that Merrew's vessels carrying the title 1 Pf Pand found in the pyramid of Djoser date back to the reign of king Ninetjer; therefore these vessles could have been among the vessels of Hebsed festival which were located in the area of the large tombs of the second dynasty to the west of the pyramid of Djoser and they reused by Djoser inside his pyramid. Therefore it was concluded that Merrew was a great scribe in the reign of this king. Accordingly, the closest reading of his title is $z h \mathrm{C}^{\mathrm{C}} z h$ which means scribe of the royal documents/ records. Thus, he was a scribe of the records or documents in the administration of records and documents in the reign of king Ninetjer.

\section{CONCLUSION}

According to the above mentioned, Merrew was a scribe in the administration of records and documents during the reign of Ninetjer of the second dynasty, it was clear, By analyzing the proposed readings of this title that the closest reading of it was $z h \mathrm{C}^{\mathrm{C}} \mathrm{C} z \mathrm{~h}$ meaning scribe of the royal documents /records. The first sign - of this title is an abbreviation of the word

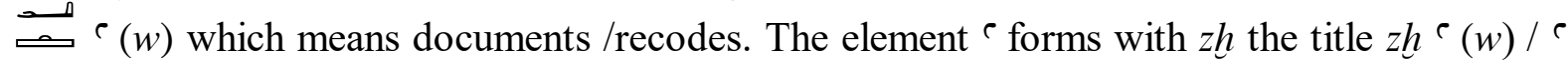
$z h / z h{ }^{c}$ which appeared in the second dynasty and continued in this form until the third dynasty. In the fourth dynasty, the word $n s w t$ was added to it, so it became $s \check{s}^{\mathrm{C}} n s w t / n s w t z h$ $c^{\prime s c r i b e}$ of the royal documents /records". This indicates that the title $z h^{\top}(w){ }^{\ulcorner} z h / z h{ }^{\circ}$ is the old form of the title $n s w t z h{ }^{c}$ which was written in variant forms. The latter title developed, and other titles were derived from it in the Middle Kingdom related to records. This title can also be compared to the title $z h \underline{h} r t{ }^{-}{ }^{\complement} n s w t$.

Paleographic between the sing pr and sing zx

\begin{tabular}{|c|c|c|c|c|c|c|}
\hline \multirow{2}{*}{$\begin{array}{c}\begin{array}{c}\text { Ref. Möller } \\
\text { Vol. } 1\end{array} \\
340,32\end{array}$} & \multirow{2}{*}{$\begin{array}{c}\text { SINGS } \\
\sqsubset \sqsupset\end{array}$} & \multicolumn{5}{|c|}{ FORMS } \\
\hline & & & $n$ & 0 & & $\begin{array}{l}\mathbf{R} \\
\boldsymbol{n}\end{array}$ \\
\hline & \multirow{7}{*}{ 酧 } & $A S A E, 28$, & $P D \mathrm{~V}$, & P.Abusir & P.Elephantine & P. Hatnub \\
\hline \multirow{6}{*}{537,51} & & fig.17. & Nr.144 & Berl 4 & $3 \operatorname{trcb}, 5$ & 14,$11 ; 24,3$ \\
\hline & & & & Dyn. 5 & Dyn.6 & Dyn.11/1 \\
\hline & & & 17 & $n$ & 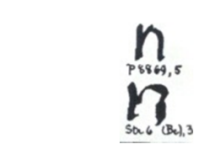 & \\
\hline & & $A S A E, 28$ & $P D \mathrm{~V}$ & P.Abusir & P.Elephantine & P. Hatnub \\
\hline & & fig. 17 & Nr.144 & Ber17/A.6 & p 8869,5;str6 & 25,$19 ; 21,1$ \\
\hline & & & & Dyn. 5 & Dyn.5 & Dyn $11 / 12$ \\
\hline
\end{tabular}

\footnotetext{
${ }^{79}$ W.Helck, $L \ddot{A} \mathrm{IV}, 509$.
} 


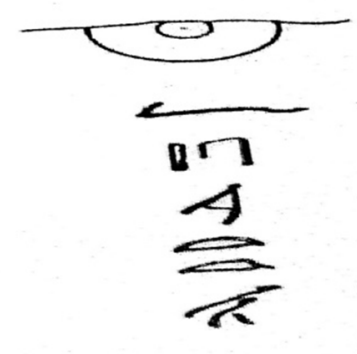

Fig.1

P.Lacau et J.-PH. Lauer, PD, V, Nr.144, fig.95, 60.

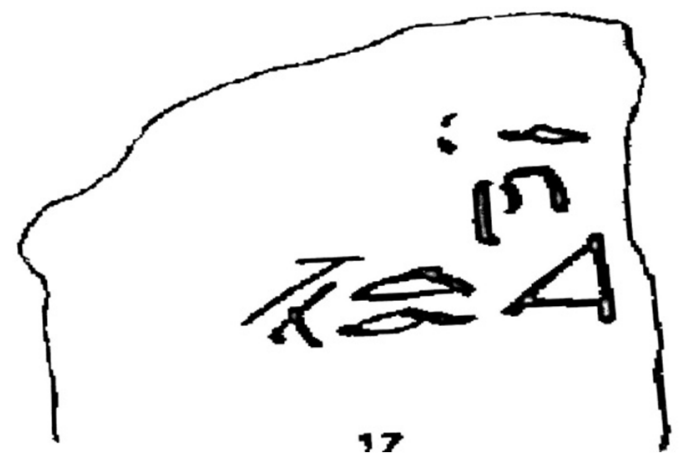

Fig.2

B.Gunn, $A S A E, 28,1928,169-170$, fig.17 .
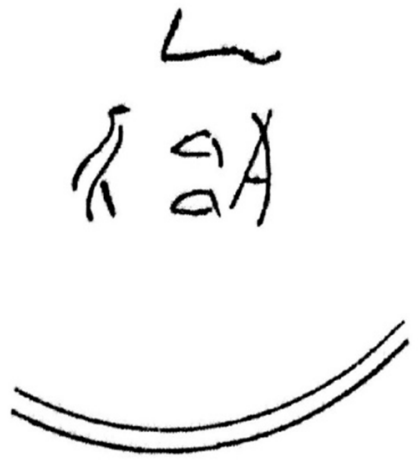

Fig.3

Lacau et J.-PH. Lauer, PD, V, Nr.145, fig.96, 61 


\section{REFERENCES}

- Assmann J.,

- Badawi A. \& Kees H.,

- Baillet J.,

- Boesser P.A.A.,

- Borchardt L.,

- Brugsch H.,

- Daressy G.,

- Davies D.G. Norman \& Macadam M.F.,

- Davies W.V.,

- Dümichen,

- Dunham D.,

- Epron L. \& Wild H.,

- Fakhry A.,

- Faulkner R.O.,

- Firth C.M.\& Quibell J.E.,

- Fischer H. G.,

-

$-$

- $\overline{\text { Gardiner A. H., }}$

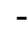

- $\overline{\text { Glanville S., }}$

- Goedicke H. ,

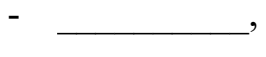

- Gunn B.,

- Hannig R.,

- Hassan S., - Helck W.,
Die Mastaba II / I zu Dahschur-Mitte, (Heidelberg, 1992).

Handwoerterbuch der Aegyptischen sprache, (kairo 1958).

'Les noms de L'esclave en Égytian' in: $R T=$ RecTrav, 28, (1908).

Beschreibung der Aegyptischen Sammlung der Niederländischen

Reichsmuseums der Altertümer in Leiden, II, (Leiden 1909).

Statuen und Statuetten von Konigen und Privartleuten im Museum von

Kairo, (Berlin 1930).

Dictionnaire géographique de l'ancienne Égypte, V, (Leipzig ,1880).

Le mastaba de Mera, (Cairo 1900).

A Corpus of Inscribed Egyptian Funerary, (Oxford, 1957).

'Tutaankhamun's Razor-Box: A Problem in Lexicography', in: JEA 63, (1977)

Baugeschichte des Denderatempels und Beschreibung dereinzelnen eile des Bauwerkes nach den an seinen Mauern befindlichen ichriften, (Strassburg - Trübner, 1877).

"The Biographical Inscriptions of Nekhebu in Boston and Cairo", in: $J t$ 24, (1938).

Le Tombeau de Ti, I, (Le Caire, 1939).

'The Excavation of Snefru's Monuments at Dahshur. Second Preliminary Repot', in: ASAE 52 (1954).

Sept tombeaux à l'est de la grande pyramide de Guizeh, (SAE) (Cairo 1935).

The Monuments of Sneferu at Dashur, II, (Cairo, 1961).

The Ancient Egyptian Pyramid Texts, (Oxford, 1969).

The Step Pyramid, II, (Cairo, 1939).

'Five Inscriptions of the Old Kingdom', in: Z̈̈S, 105, (1978).

'The Inspector of Youths Nfr-n-2wfw', in: OMRO 41, (1960).

Egyptian Studies III. Varia Nova, (New York 1996).

'The House life', in JEA, 24, (1938).

Egyptian Grammar, Begin and introduction to the Study of Hieroglyphs, third edition, (London, 1973).

Late-Egyptian Miscellanies, (Bruxelles, 1937).

'Scribes' palettes in the British Museum' in: JEA, 18, (1932).

'Ein Brief aus dem Alten Reich (Pap.Boulaq. 8)', in: MDAIK, 22, (1967).

Die Privaten Rechts inschriften aus dem Alten Reich, (Vienna 1970).

Königliche Dokumente aus dem alten Reich, (Wiesbaden 1967)

'Inscriptions from the Step Pyramid Site, III Fragments of Inscribed

Vessels', in: ASAE, 28, (1928).

Jie Sprache der Pharaonen Großes Handwörterbuch Deutsch-Ägyptisch, Mainz, 2000).

Excavations at Giza, VI, part II ( Cairo 1948).

'Das Dekret des Königs Haremheb' in: Z̈̈S, 80 (1955).

'Die Datierung der Gefäßaufscriften aus der Djoserpyramide', in: Z̈̈S, 106, Heet 2, (1979).

'Ninetjer', in: $L \ddot{A}$ IV, (1982). 
$-$

- Hermann A.,

- James T. G. H.,

- Jones D. ,

- Junker H.,

- Kahl J.,

- Kaiser W., \& Others,

- Kamal A.,

- Kanawati N.,

- Kaplony P.,

- Lacau P. et Lauer J.-PH.

- Manniche L.,

- Mariètte A.,

- Mariètte A.,

- Martin G.T.,

- Maspero G.,

- Meeks D. ,

- Mercer S.A.B.,

- Möller G.,

- Montet P.,

- Naville E.,
Unterscuchungen zur Thinitenzeit, (Wiesbaden, 1987)

Untersuchungen zu den Beamtentitln des Ägyptischen Alten Reiches, (Glückstadt, 1954)

Untersuchungen zu den Beamtentiteln des ägyptischen Alten Reiches (ÄF 18), (Glückstadt 1954)

'Buchillustrationen auf ägyptischen Bücherkästen', in: MDAIK, 15, (1957).

British Museum. Hieroglyphic Texts from Egyptian Stelae etc., Part I.

Second Edition, (London 1961).

Corpus of Hieroglyphic Inscriptions in the Brooklyn Museum. I. From

Dynasty I to the End of Dynasty XVIII, (Wilbour Monographs 6)

,(Brooklyn 1974).

Hieroglyphic Texts from Egyptian Stelae etc, in the British Museum, part

$\mathrm{I}^{2}$, (London 1962)

The Hekanakhte Papers and Other Early Middle Kingdom Documents, (New York, 1962).

An Index of Ancient Egyptian Titles, Epithets and Phrases of the Old

Kingdom, 2Vols , (Oxford 2000).

Gîza, III, (Leipzig. 1938)

as System der ägyptischen Hieroglyphenschrift in der 0.-3. Dynastie, riesbaden, 1994).

Fühägyptisches Wörterbuch,( Wiesbaden,2002

'Stadt und Tempel von Elephantine. 13./14. Grabungsbericht', in: MDAIK, 43, (1987).

'Le tombeau nouveau de Méîr (1913-1914)', in: $A S A E, 16,(1916)$.

The Egyptian Administration in the Old kingdom, (Warminster 1977).

'Der Schreiber, das Gotteswort und diepapyruspfianze Mit neuen untersuchungen zum unter ägyptischen Königtum', in: Z̈̈S , 110, (1983).

Die Inschriften Der Ägyptischen Frühzeit, Band, I, (Wiesbaden, 1963).

Die Rollsiegel des Alten Reiches. II: Katalog der Rollsiegel, (Bruxelles, 1981).

La Pyramide á Degrés, Inscriptions á L'encre Sur les Vases, Tome V, (Cairo, 1965).

Lost Tombs. A Study of Certain Eighteenth Dynasty Monuments in Theban Necropolis, (London 1988).

Dendérah : description générale du grand temple, IV, (Paris ,1875).

Les mastabas de l'Ancien Empire, (Paris, 1889).

'Private-Name Seals in the Alnwick Castle Collection', in:MDAIK (1979).

The Tomb of Hetepka and Other Reliefs and Inscriptions from the sacred Animal Necropolis, North Saqqara 1964-73, (London, 1979).

Études de mythologie et d'archèologie ègyptiennes, II, (Paris 1893-

1916).

, Annee Lexicographique Egypte Anceinne, 3tome, (Paris, 1980-1982).

The Pyramid texts, in translation and Commentary, ( London 1952).

Hieratische Paläographie: die ägyptische Buchschrift in ihre Entwicklung von der fünften Dynastie bis zur römischen Kaiserzeit, Bd. ,(Leipzig, 1909)

Les Scènes de la vie privèe dans les tombeaux ègytiens de l'Ancien Empi (Paris 1925).

Das ägyptische Todtenbuch der XVIII. bis XX. Dynastie, (Beriln 1886). 
- Newberry P.E., Egyptian antiquities: scarabs; an introduction to the study of Egyptian seals and signet rings, (London 1906).

- Petrie H.F. \& Seven Mempite chapels, (London 1952).

Murray M.A.,

- Pflüger K.,

- Piacentini P.,

'The edict of king Haremhab', in: JNES, 5, (1946).

Les Scribes dans la Soiété égyptienne de l'Ancien Empire, Les Premiéres lynasties, Les nécropoles Memphies, Vol 1, (Paris ,2002).

- Posener-kriéger Les archives du temple funéraire de Néferirkarê-Kakaï (Les papyı P., d'Abousir). Traduction et commentaire, Vol II., (Le Caire 1976).

- Rank H., D Die Ägyptischen Personennamen, Band I, (Glückstadt, 1935).

- Sethe K., $\quad$ Altaegyptischen PyramidenTexte, vol II, (Leipzig, 1910)

- Simpson W.K., $\quad$ The Mastabas of Qar and Idu. G 7101 and 7102. (Giza Mastabas 2), (Boston 1976).

- Spencer A.J., , Early Egypt. The Rise of Civilization in the NileValley, Translated to Arabic by A. Aldali, review by T.Hindusa, (Cairo 1991).

- Strudwick N., The Overseer of the Treasury Ny-kAw-PtH', in RdE, 38, (1987).

- $\longrightarrow$ Cylinder Seals of the Old kindom, (Oxford,1978).

- $\quad$ The Administration of Egypt in old Kingdom, (London, 1985).

- Vittmann G., $\quad$ Priester und Beamte im Theben der Spätzeit, (Wien,1978).

- Ward WA., 'Old Kingdom sS a n nsw n xft-Hr, "Personal Scribe of Royal Records", and Middle Kingdom sS an nsw n xft-Hr, "Scribe of the Royal Tablet of the Court', in: Or, 51, (1982).

Index of Egyptian Administrative and Religious Titles of the Mid. Kingdom, (Beirut, 1982).

- Wilkinson R.H., $\quad$ Reading Egyptian Art: A Hieroglyphic Guide to Ancient Egyptian

Painting and Sculpture, (London 1994).

- Wood W., 'A Reconstruction of the Reliefs of Hesy-re', in: JARCE, 15, (1978). 